\title{
THE RELIGIOUS LIFE OF ROMANIANS IN 18TH-20TH CENTURY HUNGARY REFLECTED IN THE WORKS OF RESEARCHERS IN THE HUNGARIAN SPACE
}

\author{
ALIN CRISTIAN SCRIDON \\ Faculty of Letters, History and Theology, West University of Timisoara \\ Bulevardul Vasile Pârvan 4, Timişoara 300223, Romania \\ E-mail address: alin.scridon@e-uvt.ro \\ ORCID: https://orcid.org/0000-0003-4576-0591
}

\begin{abstract}
Aim. We tend to believe that the religious life of Romanians in the diaspora - living in the proximity of the Romanian borders (we do not take into account the groups that left towards Spain, Italy, Germany, and so on at the beginning of the third millennium) - is a taboo subject. The Orthodox (Romanian) clerical elite focused less on the assiduous study of the religious life of their Romanian brothers outside the borders; in this case, in Hungary. Therefore, we have the scientific duty-but more importantly, the moral duty - to bring to light the truths that are either not known or are known in a distorted form. The road of Voniga (Giula-Giroc) that we followed during the PhD research period was a blessing from the point of view of a scientific void/niche.

Methods. In our study, we have applied two "simple" components: the archive and the specialised bibliography.

Results. The archive was largely preserved only by Elena Csobai and Emilia Martin. The respectable ladies professionally structured the archive (Romanian Orthodox Church in Hungary) and saved hundreds of research sources from the depth of history.

Conclusion. As Moisa noted (2011), the puzzling ethnographic, linguistic, cultural, and historical bulk material is without a doubt focused on the Church. The church is inextricably linked to the lives of Romanians in Hungary. Going through the tens of thousands from the mentioned fields, even superficially, there is an undeniable truth: the spirituality is present, more or less, in the writings of most of the select researchers who have worked in the scientific field for the past three decades.
\end{abstract}

Key words: The Romanian Orthodox Church, Hungary, Elena Csobai, Emilia Martin

$\mathrm{t}$ the end of 2019, a reader could enjoy online access to no less than 13,163
zion, Lumina, Izvorul and Annales publications accumulate 8,553 pages, and the
19 volumes (which can be downloaded from the above-mentioned site) com-

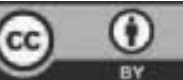


plete the bibliography by another 4,610 pages. It is part of an extremely accessible bibliography, which we recommend for reading.

Among the works that can be accessed in the same way we mention: Chitighaz. Pagini istorico-culturale (Berényi, 1993); Bătania. Pagini istorico-culturale (Berényi, 1995), Micherechi. Pagini istorico-culturale (Berényi, 2000), Cultură românească la Budapesta în secolul al XIX-lea (Berényi, 2000); Viața și activitatea lui Emanuil Gojdu. 1802-1870 (Berényi, 2002); Moștenirea lui Gojdu în oglinda presei române și maghiare (1995-2005) (Berényi, 2005); Poveștile caselor. Români în Buda și în Pesta (Berényi, 2011); Sărbătorile calendaristice ale românilor din Ungaria (Martin, 2003); Institutul de cercetări al românilor din Ungaria. Un deceniu de existență. 1993-2003 (Berényi, 2003); Personalități marcante în istoria și cultura românilor din Ungaria (Secolul XIX). Studii (Berényi, 2013); Vestigiile Bisericii Ortodoxe Române din Ungaria (Csobai\& Emilia, 2013); Românii din Ungaria. Studii de etnologie (Martin, 2013); Românii din Ungaria. Studii de istorie (Csobai, 2013); Limbă română și identitate românească în Ungaria - Aspecte dialectologice, sociolingvistice, onomastice și demografice (Borbély, 2013); Aspecte ale gândirii umane. Studii de psihologie tradițională (Nikula, 2013); Săcalul de altădată (Garami, 2013); Institutul de Cercetări al Românilor din Ungaria. 25 de ani de activitate. Volum jubiliar (Berényi, 2018); Confesiunea în romanul românesc interbelic (Hergyán, 2012) și Picturi/Sculpturi/Lucrări de grafică (Oroian, 2013).

Regarding books, studies and reviews (in Romanian) published in the Hungarian space, the ones who wrote about spirituality in general and on the religious life of Orthodox Romanians in Hungary were, among others, Iosif Ioan Ardelean, Teodor Misaroș, Elena Csobai, Emilia Martin, Maria Berényi, Stella Nikula, Elena Rodica Colta, Eugen Glück, Mészáros Zsuzsanna, Gheorghe Santău, Cornel Sigmirean, Maria Gurzău Czeglédi, Nagy Márta, Ana Radici Repiský, Marius Maghiar, Eva Kozma, Ana Borbély, Gyöngyi Mocan, Ana Hoțopan, Alexandru Hoțopan, Siluan Mănuilă, Mihaela Bucin, Aurel Chiriac, Nicolae Bocșan, Ion Cârja, Aurel Becan, Maria Petrușan, Ovidiu Pecican, Ioan Octavian Rudeanu, Aurica Cioca, Lucia Borza, Corina Teodor, Corneliu Pădurean, Gheorghe Chivu, Maria Dan, Teodor Marc, Maria Ambruş, Grigore Poiendan, Andreea Buzaș, Mircea-Gheorghe Abrudan, Daniela Răuțu, Tiberiu Boca, Viorel Dorel Cherciu, and Alin Cristian Scridon.

Periodical publications published online, such as Simpozion, Annales, Lumina, Izvorul, comprise 138 articles and studies with a theological profile written by 42 authors (only 6 being clerics).

Harnessing the spiritual component of the above-mentioned vast online bulk material, we try to promote it by publishing in exclusively theological journals the studies such as The religious life of the Romanian Orthodox in Hungary - a fundamental component in the work of Elena Csobai (Scridon, 2019); Ghenadie Bogoevich - controversial Monk in the Horthyst Hungary" (Scridon, 2018); A researcher and his work Delimitation of the spiritual component in the work of Maria Berényi (Scridon, 2020).

We are also trying to prepare articles during this year that bring to light the approach to Romanian spirituality (in addition to the two, already addressed 
names: Maria Berényi and Elena Csobai) by Emilia Martin, Stella Nikula, Elena Rodica Colta, Eugen Glück, Nagy Márta, Cornel Sigmirean.

The tens of thousands of pages written by the eight researchers, all laypeople without theological courses, with PhDs in history and philology (Sigmirean is also a PhD supervisor in the field of history) were a surprise for me because, as a clergyman, I believe that the presence of the Church's work is the component that is often missing today from the minimal spiritual baggage.

The history of the Romanian Orthodox Church managed to bring to light in the last century the fundamental themes from the ecclesiastical past. The foundations' themes related to the Church history of Romanians are known in the Romanian space through the writings of the undeniable leader, the priest Mircea Păcurariu. Păcurariu remains a pioneer in the Romanian church history as, owing to his work, the Romanian theology students know well themes such as the beginnings of christianity on the territory of our country; archaeological evidence of the spread of christianity in Dacia; the first metropolis in Moldova; the first metropolis in Wallachia, etc. (Păcurariu, 2000). The mentioned volume is considered one of the most important readings in the minimal bibliography that a theology student is obliged to go through. Therefore, the volume has a lot of editions.

On the other hand, it must be admitted that until the end of the last century, Păcurariu was the only one who, as a theologian, was coordinating PhD studies in the Church history field in Transylvania. The PhD students contributed to the undertaking but the research paths of ecclesiastical history were plenty. At some point, it was necessary to slowly reveal new information that would enrich the existing bibliography in the historiography scene.

In addition to the research activity undertaken by the priest Păcurariu and his doctoral students (who later became professors and $\mathrm{PhD}$ supervisors themselves), a significant role in discovering the realities endorsed by the Church and their promotion was the one played by the lay professors from Babes Bolyai University from Cluj-Napoca.

At the University of Cluj-Napoca, Nicolae Bocşan was impressively active until June 16, 2016, when he died. Being PhD supervisor in the field of history, Bocşan assumed the role of the leader in Transylvania and Banat and managed to solve a series of themes that were published and are currently in the university libraries and the Church.

The books published by Bocşan, and especially the PhD students, have covered another important area from the historical past of the Romanian Orthodox Church.

The Hungarian researchers mentioned in this study were not trained in the theological centre in Sibiu (Mircea Păcurariu), but were schooled in the University of Cluj-Napoca, under the guidance of Bocșan, the current president of the Romanian Academy Ioan Aurel Pop, the academic Ioan Bolovan, the professor Cornel Sigmirean and others. For example, Maria Berényi, the director of the Romanian Research Institute in Hungary, after finishing her doctoral degree in philology at the "Eötvös Lóránd" University in 1986, promoted her second doctoral study in history in 2001 at the University of Cluj Napoca. 
The Romanian Research Institute in Hungary organises a highly rated symposium every year in November, starting from 1991. The symposium has so far enjoyed the presence of a significant number of academics and prestigious teachers in Romania. In 2019, the symposium had its 29th edition. In no symposium (this year will be the 30th edition), Mircea Păcurariu or any Romanian significant ecclesiastical historian was present. I was the only clergyman historian who presented a communication at the Giula Symposium in the autumn of 2013 (23rd Symposium). I was granted, in a way, the consent to be a researcher through the lay branch of the University of Cluj Napoca.

It should be mentioned that the universities in Cluj-Napoca and Sibiu are not institutions that are antagonistic, malicious or that have something to argue upon. Each institution has simply formed over time its symposia, its rhythm, its collaborators.

The Hungarian symposium debates topics related to the lives of Romanians in the Hungarian area. In this broad spectrum of the meticulously analysed themes, there is also the spiritual component.

The analysed bibliography testifies that the works and the research undertaken by the Romanian elite in Hungary are a truly rich source, which must be exploited maybe not by an army of theological researchers, but at least by a few.

The historical research has well-known international rules, the steps that need to be taken in order to outline a truth. However, I would like to argue that the analysis of a church subject undertaken by a historical clergyman (in this case, regarding the wide archival background and the bibliography offered by the mentioned Romanian laity) may be slightly different. A clergyman knows the mentality of the guild which he is a member, of knows the petition path and the communication paths of the bishops, makes connections with ecclesial realities from other regions or times, and so on.

On the other hand, the Church is not only the institution of priests but also of believers. I would like to put forward an opinion that it is firstly an institution of the believers and then an institution of the priests. Therefore, every member of the Church, layman or priest, is responsible for honestly presenting historical events from the past of the Church. Today, however, not many people are aware of the role played by the Church over the centuries, but everyone knows the sins of the Church presented by the media.

Nevertheless, there is a group of laypeople who research the role played by the Romanian Orthodox Church in the localities with Romanian ethnicities in Hungary between the 17th and 20th centuries.

The scientific work of the researchers in Hungary is significant, and it is focused on an ideal and idealistic Church. For example, Elena Csobai describes in detail the activity of the priests David Voniga (Csobai, 2003), Simeon Cornea (Csobai, 2011), Iosif Ioan Ardelean (Csobai, 1993). Csobai publishes historical data on the Church, dividing the information gathered into the following themes: documentary attestation of the locality; information related to the construction of the church; the patrimony of the church; the role of foundations in 
preserving Orthodox spirituality; the denominational school (establishment; presentation of teachers; tables with the number of pupils, etc.). In this 'section' of she works, the Romanian researcher carefully evaluates, for example, the problem of denominational schools. Therefore, through the truths discovered and published, Csobai shows that Romanian Orthodox priests from the Hungary of past centuries have made an overwhelming contribution to the structure of Romanian culture and spirituality in the parish received for pastoral care.

Simultaneously, Csobai shows that newspapers printed in the Romanian language of the 19th century "became more and more widespread among Romanians in Hungary due to the activity of the church" (Csobai, 1998). Another merit attributed to the Church is its contribution to establishing "reading circles, choral and theatrical ensembles, folk dance groups" (Csobai, 1998).

From the plethora of contributions given to the Church, I would like to focus only on one: "(...) synthesising the decisive contribution of the Romanian Orthodox Church in the preservation of identity, we can say categorically that in the nineteenth century this role rests exclusively because it was the only institution carrying the Romanian identity" (Scridon, 2020).

Due to the role of the institution promoting philanthropy, culture, language, etc., ethnic identity has attracted the state's aversion. Csobai briefly presents this relationship of the Hungarian State with the Romanian Orthodox Church in Hungary claiming that "the priests (Romanian Orthodox from Hungary) were always (during the interwar period) supervised by the police" (Scridon, 2017).

On the other hand, the following appreciation of the Church is present in the work of Maria Berényi: "There are few European nations that owe so much to the church and to the clergy as to the Romanians from Transylvania and Hungary" or "(...) the first condition to become a good Romanian was to be a good Christian." (Scridon, 2020). The importance of religion is perfectly explicable in a society based on a Christian order, in which religion has long served the Romanian as a means of identification and solidarity (Scridon, 2020).

Elements of the plans proposed and implemented to tear down the Romanian Orthodox Church in Hungary are continuously being discovered by the researchers. At the same time, in addition to the external actions, the Hungarian officials wanted to have a man inside the Church, obviously in the best position. For example, in 2016 Cornel Sigmirean, after consulting the Archive of the Ministry of Foreign Affairs of Romania, disseminates in the research horizon the following information: "(...) at the beginning of the 20s, as it appears from the documents in the Archive of the Ministry of Foreign Affairs of Romania, the idea of setting up an Episcopate of Romanians in Hungary appeared. The initiative belonged to the Hungarian government, and the Bishop Ghenadie Gh Bogoevici was proposed" (Sigmirean, 2016).

The Romanian Ministry of Foreign Affairs, Sigmirean (2016) specifies, opposed the appointment of Bogoevici as Romanian bishop in Hungary and thus the plan prepared in Budapest was cancelled. 


\section{CONCLUSION}

The Romanian ethnic researchers in Hungary, basing their research on the archival documents and bibliography, present the honest historical facts about the religious life of Romanians in Hungary from the 18th to the 20th century.

For the Romanian ethnic in Hungary, the Church was the institution that strongly preserved the customs, culture and language. The church was that Alma Mater that reminded of the ancestors, traditions, and values common for this ethnic group from Eastern Europe.

\section{REFERENCES}

[1] Berényi, M. (Ed.). (2000). Micherechi. Pagini istorico-culturale [Micherechi. Historical-cultural pages]. Gyula, Hungary: Institutul de Cercetări al Românilor din Ungaria.

[2] Berényi, M. (2000). Cultură românească la Budapesta in secolul al XIX-lea [Romanian culture in Budapest in the 19th century]. Gyula, Hungary: Schneider Nyomda.

[3] Berényi, M. (2002). Viața şi activitatea lui Emanuil Gojdu. 1802-1870 [The life and activity of Emanuil Gojdu. 1802-1870]. Békéscsaba, Hungary: Mozi Nyomda Bt.

[4] Berényi, M. (2002). Moștenirea lui Gojdu în oglinda presei române și maghiare [Gojdu's legacy in the mirror of the Romanian and Hungarian press]. Békéscsaba, Hungary: Mozi Nyomda Bt.

[5] Berényi, M. (Ed.). (2003). Chitighaz. Pagini istorico-culturale [Chitighaz. Historical-cultural pages]. Budapest, Hungary: Comp-Press Kft.

[6] Berényi, M. (Ed.). (2003). Institutul de cercetări al românilor din Ungaria. Un deceniu de existență. 1993-2003 [The Romanian Research Institute of Hungary. A decade of existence. 1993-2003]. Gyula, Hungary: Schneider Nyomda.

[7] Berényi, M. (Ed.). (2005). Bătania. Pagini istorico-culturale [Bătania. Historical-cultural pages]. Budapest, Hungary: Comp-Press Kft.

[8] Berényi, M. (2011). Poveștile caselor. Români în Buda și în Pesta [Tales of houses. Romanians in Buda and Pest]. Gyula, Hungary: Dürer Nyomda Kft.

[9] Berényi, M. (2013). Personalități marcante în istoria și cultura românilor din Ungaria (Secolul XIX). Studii [Famous Romanian celebrities in the history and culture in Hungary (19th century). Articles]. Gyula, Hungary: Dürer Nyomda Kft.

[10] Berényi, M. (Ed.). (2018). Institutul de Cercetări al Românilor din Ungaria. 25 de ani de activitate. Volum jubiliar [The Romanian Research Institute of Hungary. 25 years of activity. Jubilee volume]. Gyula, Hungary: Schneider Nyomda.

[11] Borbély, A. (2013). Limbă română și identitate românească în Ungaria [The Romanian language and Romanian identity in Hungary]. Gyula, Hungary: Dürer Nyomda Kft.

[12] Csobai, E. (1993). Personalități marcante. Iosif Ioan Ardelean (1849-1920) [Outstanding personalities. Iosif Ioan Ardelean (1849-1920)]. In M. Berényi (Ed.), În amintirea lui Iosif Ioan Ardelean. Chitighaz. Pagini istorico-culturale (pp. 21-23). Budapest, Hungary: Comp-Press Kft.

[13] Csobai, E. (1998). Rolul Bisericii Ortodoxe în păstrarea identității la românii din Giula [The role of the Orthodox Church in preserving the identity of the Romanians from Giula]. In: Berényi, Maria, (Ed.), Simpozion. Comunicările celui de al VII-lea simpozion al comunității cercetătorilor români din Ungaria (pp. 78-86). Gyula, Hungary: Noi Publishing House.

[14] Csobai, E. (1999). Aspecte din istoria românilor din Giula [Aspects from the history of the Romanians from Giula]. In: Berényi, Maria, (Ed.), Simpozion. Comunicările celui de al VIII- lea simpozion al comunității cercetătorilor români din Ungaria (pp. 65-74). Békéscsaba, Gyula, Hungary: Nyomtatás Mozi Nyomda Bt.

[15] Csobai, E. (2003). David Voniga în presa românească [David Voniga in the Romanian press] Lumina. Revistă socială, culturală și științifică a românilor din Ungaria. Fondată de David Voniga în 1894, 24-26.

[16] Csobai, E. (2011). Simion Cornea, luptător pentru organizarea parohiilor ortodoxe române 
într-o eparhie [Simion Cornea, the fighter for organization of the Romanian Orthodox parishes in a diocese]. In: Berényi, Maria, (Ed.), Simpozion. Comunicările celui de al XX-lea simpozion al comunității cercetătorilor români din Ungaria (pp. 100-114). Békéscsaba, Gyula, Hungary: Nyomtatás Mozi Nyomda Bt.

[17] Csobai, E. (2013). Românii din Ungaria. Studii de istorie [The Romanians in Hungary. Historical research]. Gyula, Hungary: Dürer Nyomda Kft.

[18] Csobai, E., \& Martin, E. (2013). Vestigiile Bisericii Ortodoxe Române din Ungaria [Vestiges of the Romanian Orthodox Church in Hungary]. Gyula, Hungary: Dürer Nyomda Kft.

[19] Hergyán, T. (2012). Confesiunea in romanul românesc interbelic [The confession in the Romanian interwar novel]. București, România: Tracus Arte.

[20] Iszály Garami, I. (2013). Săcalul de altădată [Săcal of yesteryear]. Gyula, Hungary: Dürer Nyomda Kft.

[21] Martin, E. (2003). Sărbătorile calendaristice ale românilor din Ungaria [Calendar with holidays of Romanians in Hungary]. Gyula, Hungary: Four Color Kft.

[22] Martin, E. (2013). Românii din Ungaria. Studii de etnologie [The Romanians in Hungary. Ethnology articles]. Gyula, Hungary: Dürer Nyomda Kft.

[23] Moisa, G. (2010). Istoriografia românilor din Ungaria 1920-2010. Între deziderat și realitate [Historiography of Romanians in Hungary 1920-2010. Between desideratum and reality]. Gyula, Hungary: Noi Publishing House.

[24] Nikula, S. (2013). Aspecte ale gândirii umane. Studii de psihologie tradițională [Aspects of human thinking. Traditional psychology articles]. Gyula, Hungary: Dürer Nyomda Kft.

[25] Oroian, Ș. (2013). Picturi/Sculpturi/Lucrări de grafică [Paintings/Sculptures/Graphic works]. Gyula, Hungary: Dürer Nyomda Kft.

[26] Păcurariu, M. (2000). Istoria Bisericii Ortodoxe Române [History of the Romanian Orthodox Church], (pp. 17-89). 5th Edition. Bucarest, Romania: Sofia Publishing House.

[27] Scridon, A. C. (2017). The activity of Toma Ungureanu as a priest in the parish of Gyula. The correspondence between 1922-1934. In: Scridon, Alin Cristian, (Coord.), Banat-Europe: Theology, History and Culture (119-128). Szeged, Hungary: Jate Press Publishing.

[28] Scridon, A. C. (2018). Ghenadie Bogoevici - a controversial Monk in the Horthyst Hungary. International Journal of Orthodox Theology, 9(4), 202-219.

[29] Scridon, A. C. (2019). The religious life of the Romanian Orthodox in Hungary - a fundamental component in the work of Elena Csobai. International Journal of Orthodox Theology, 10 (3), 89-108.

[30] Scridon, A. C. (2020). A Researcher and Her Work. The Delimitation of the Spiritual Component in Maria Berényi's Work. International Journal of Orthodox Theology, 11(1), 162-191.

[31] Sigmirean, C. (2016). Despre înființarea unei episcopii ortodoxe a românilor din Ungaria [About the establishment of an Orthodox diocese of Romanians in Hungary]. In: Berényi, Maria, (Ed.), Simpozion. Comunicările celui de al XXV-lea simpozion al cercetătorilor români din Ungaria (pp. 55-61). Gyula, Hungary: Schneider Nyomda Kft. 